\title{
Cuando las negras de Chambacú se QUERÍAN PARECER a María FÉlIX
}

\author{
Por: Mercedes Posada Meola
}

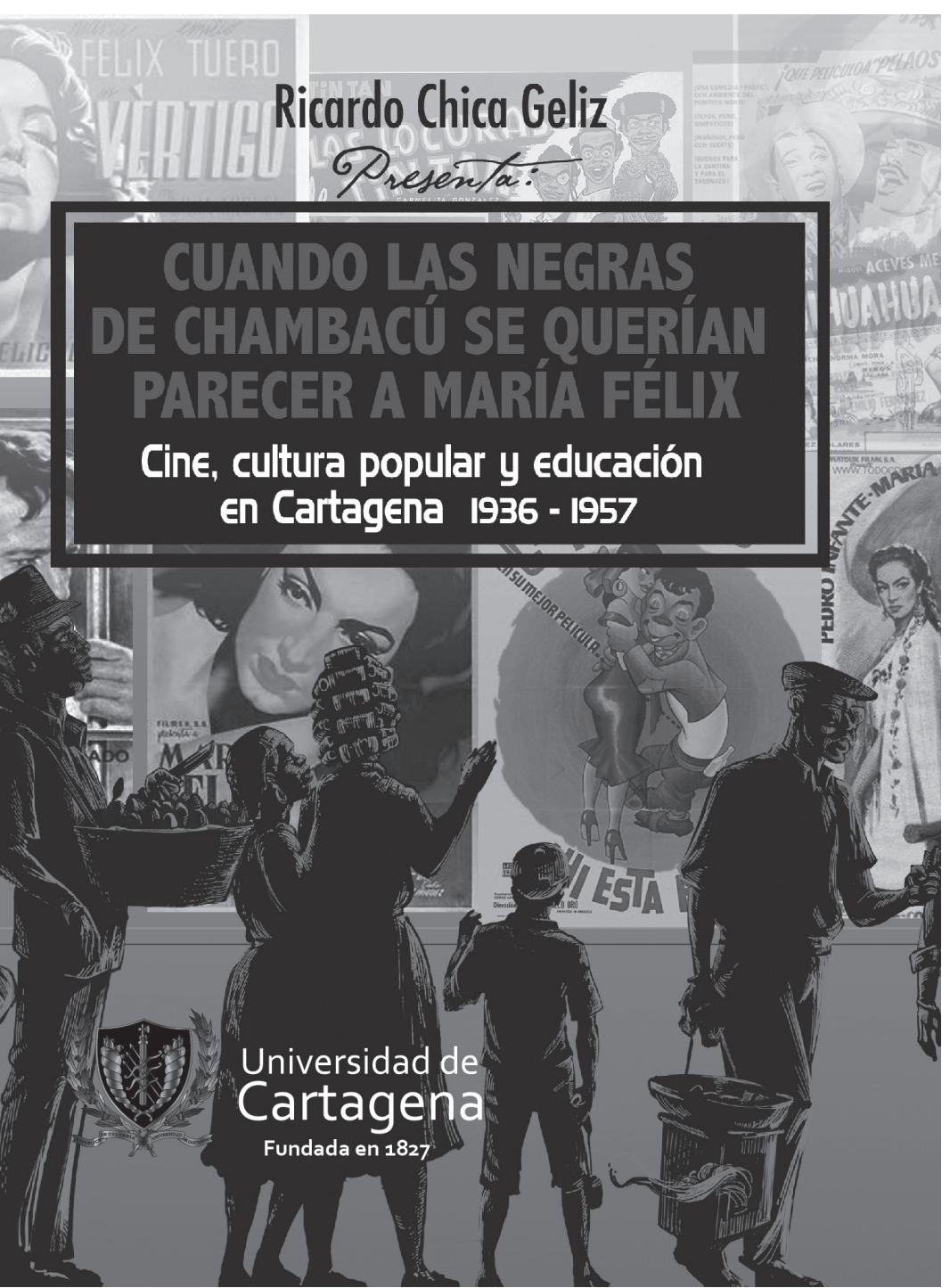

Desentrañar los eslabones que intervinieron en la relación cine, cultura popular y educación en Cartagena de Indias, durante el período comprendido entre 1936 y 1957, es el propósito del libro Cuando las negras de Chambacú se querían parecer a María Félix, escrito por el profesor Ricardo Chica Geliz, como resultado de una investigación cualitativa en la que propone cuatro planos de análisis: la educación y la cultura, la historia, el cine y el público, la modernidad y la geografía urbana, y la subalternidad y los aspectos étnicos raciales.

En el año 1936, conforme lo revela Chica en el texto, Cartagena contaba con dos emisoras radiales y una veintena de salas de cine. La televisión llegó más tarde. El periodo estudiado corresponde a la época dorada del cine mexicano, cuyas producciones fueron proyectadas a lo largo y ancho de Latinoamérica. En 1957 se produjo un declive en esta industria cinematográfica tras la muerte de su máximo ídolo, Pedro Infante. En Colombia llega a su fin la dictadura del presidente Rojas Pinilla y se da inicio al periodo conocido como el Frente Nacional. Tres años después, el cartagenero Víctor Nieto fundaría el Festival de Cine de Cartagena, el más antiguo de toda Lantinoamérica. De manera que en el periodo estudiado convergen tres elementos: la emergencia de la poderosa industria cinematográfica de México, la aparición de políticas educativas y culturales -propias de la República Liberal de A. López Pumarejo- con miras a modernizar al pueblo, y la consolidación de los medios de comunicación y 
sus mercados en la nación colombiana.

El libro está dividido en tres partes. En la primera se contextualiza la teoría, se ofrece una reflexión histórica sobre la relación entre educación, cine y cultura popular y se da cuenta de la metodología empleada para capturar y sistematizar la información. En la segunda parte se revela el concepto de apropiación social de la modernidad cultural y su dimensión práctica en Cartagena. Aquí también se hace un análisis de las películas más relevantes de la época y sus elementos formales y narrativos, para proponer una discusión sobre los imaginarios sociales cartageneros en torno a los modelos de identidad, familia, raza y género. Por último, el libro ofrece una mezcla de fuentes primarias y secundarias de información, que combina relatos de la gente con archivos históricos, para dar cuenta de la memoria fílmica en Cartagena.

Apelando al concepto de "fabulación" desde Michael De Certeau, que se entiende como el proceso de "escribir la irrupción de lo otro, desde los márgenes, desde los bordes del sistema", el profesor Ricardo Chica en su investigación se propone comprender el proceso de apropiación social de las tramas puestas en escena en las películas mexicanas que por aquellos días se proyectaban en las salas de cine la ciudad, y revela las tácticas de aceptación y resistencia que puso en juego la audiencia frente a los mensajes.

Se trata de una investigación rigurosa en su fondo y forma, que combina diferentes técnicas de investigación cualitativa, con un ejercicio hermenéutico en el que la memoria social de las personas que vieron cine en el periodo estudiado, cobra un especial valor para entender el contexto de la ciudad y sus repercusiones en el presente. Claramente Chica nos habla de un receptor activo frente a los mensajes que consume del melodrama y se aparta de la visión apocalíptica que postularon los críticos de la Escuela de Frankfurt en cuanto a la audiencia, considerada por ellos como una masa inmutable y homogénea.

Además del aspecto comunicacional, la investigación pone de manifiesto la diferencia entre educar (formación moral) e instruir (adquirir conocimientos) y revela la intención adoctrinante y distractora que subyace en los melodramas proyectados. Las negras de Chambacú se querían parecer a María Félix, la diva mexicana de aquellos años y sus personajes, especialmente porque fue el primer ícono latinoamericano de la modernidad cultural que daba cuenta de un modelo de mujer luchadora, capaz de desafiar o cuestionar al macho mexicano de su época y reubicar los elementos de la tradición latinoamericana, mas no desaparecerla. 
La materialización de lo anterior puede rastrearse en los testimonios que son incorporados a este trabajo por Chica, como un recurso para conectar evidencias prácticas y teóricas que ayudan a organizar la experiencia de relacionar cine y modernidad en Cartagena. Las escenas proyectadas en la pantalla, a pesar de las diferencias culturales que podía haber entre México y Colombia, representaban personajes muy cercanos a los que se encontraban en la cotidianeidad de la ciudad y de algún modo generaron esperanza. Los negros, por ejemplo, aparecían como personajes alegres y llenos de ritmo, de modo que las vicisitudes de la carga racista que llevaban consigo podían pasar desapercibidas ante la oportunidad de reconocerse.

Las tramas de las películas proyectadas eran redundantes y predecibles, pero al tiempo se postulaban como un bálsamo para hacer más llevadera una cotidianeidad cargada de injusticia y atravesada por un sistema sociorracial excluyente y desesperanzador que ayudaba a perpetuar la pobreza y la concentración de la riqueza en medio de una sociedad clasista, que en parte entendió la modernización como el blanqueamiento de la raza.

En aquella época, cuenta Chica, Cartagena tenía menos de 100.000 habitantes y cerca de la mitad de la población era analfabeta. No obstante, y desafiando los postulados de la aguja hipodérmica (teoría que habla de una audiencia pasiva a la que se le inyectan los mensajes a manera de jeringa), el espectador analfabeta es considerado un sujeto activo frente a los contenidos que consumía. Las clases populares - dice Chica que dice Barbero- "invierten deseo y extraen placer", de esa cultura (la hegemónica) que les niega como sujetos (de derecho). De allí que a pesar del propósito alienador que caracterizaba a las instituciones mediadoras, la población cartagenera no se volvió más homogénea, ni tampoco se correspondió plenamente con el modelo propuesto. Lo que ocurrió fue un proceso de mediaciones en el cual intervinieron el cine, los medios, otras instancias de poder (como la iglesia, el Estado y la escuela) y la vida misma para construir un nuevo sentido.

"Las clases subalternas asumen, porque no les queda de otra, una industria vulgar y pedestre y la transforman en fatalismo, en autocomplacencia y degradación, pero también en identidad regocijante y combativa". Y es aquí donde se genera una especie de pacto comunicativo con el público: cada película proyectada tiene la apariencia de novedad, lo cual es un recurso propio de la industria cultural, pero en últimas es una simulación porque no se trata de un mensaje que emerja de las masas, sino que está hecho para las masas. No obstante, si bien el cine pudo reforzar el modelo hegemónico, 
como de hecho lo hizo: quererse parecer a María Félix era querer no parecer tan negra y de algún modo sucumbir o quizás esquivar los rigores implacables del olvido social y el negacionismo histórico de la ciudad, lo cual bien puede rastrearse desde la colonización hasta nuestros días. Pero al tiempo, el cine tuvo la potencia de ofrecer lecturas alternativas al modelo imperante, incluso contrahegemónicas. De allí que los valores promovidos algunas veces eran cuestionados por un sector tradicionalista de la élite cartagenera que tildaba de inmoral a los personajes.

La evidencia de estas lecturas, que de acuerdo con Hall pueden rechazar, negociar o aceptar el código, se observa tanto en los relatos de las personas que fueron entrevistadas para esta investigación y la forma en que incorporaron los diálogos de las películas a su vida cotidiana, como en los escritos que aparecieron publicados en los periódicos y revistas que circularon en la época.

Después de este recorrido, ¿por qué leer el libro Cuando las negras de Chambacú se querían parecer a María Félix? Primero, porque ofrece elementos contextuales para entender los agentes mediadores en el proceso de construcción social del sentido durante un periodo específico en la ciudad de Cartagena. Segundo, porque es darse la oportunidad de encontrar un riguroso análisis que conjuga lo histórico (desde la memoria social) con lo teórico y epistemológico para así dar cuenta de las contradicciones tanto de las políticas educativas del Gobierno Nacional y sus fines modernizadores, como de las estrategias de apropiación y resistencia que puso en juego la audiencia que vio Allá en el rancho grande y otros clásicos del cine mexicano. Y, tercero, porque es un texto indispensable para comprender y analizar la relación entre apropiación social del conocimiento a través del cine, los medios y la vida misma. 